\title{
Expansion by Ballot Initiative: Challenges and Future Directions in Health Policy
}

\author{
Phillip M. Singer, PhD, MHSA ${ }^{1,2}$ and Daniel B. Nelson, BS 3,4 \\ 'Department of Political Science, University of Utah, Salt Lake City, UT, USA; ${ }^{2}$ Department of Population Health Sciences, University of Utah School of \\ Medicine, Salt Lake City, UT, USA; ${ }^{3}$ University of Michigan Medical School, Ann Arbor, MI, USA; ${ }^{4}$ Harvard Kennedy School of Government, \\ Cambridge, MA, USA.
}

Since 2017, four states have successfully adopted the Medicaid expansion through ballot initiative. We analyze how states could potentially use ballot initiatives to implement these programs. We find there are serious legal and political challenges to expansion by initiative. Only six non-expansion states allow for a ballot initiative to pass and implement the Medicaid expansion. Amongst those states, there are challenges that limit the development, scope, and implementation of an initiative. Whether a state adopts the Medicaid expansion has important implications for health care providers.

KEY WORDS: Medicaid; health policy; health reform.

J Gen Intern Med 34(9):1913-5

DOI: $10.1007 / \mathrm{s} 11606-019-05051-1$

(C) Society of General Internal Medicine 2019

$\mathrm{W}$

hen Maine became the 33rd state to adopt the Medicaid expansion in November 2017, it was the first instance of the public bypassing the legislative and executive branches to authorize coverage expansion under the Affordable Care Act (ACA) by ballot initiative. Despite ongoing challenges with implementing its Medicaid expansion, the electoral success in Maine spurred advocates in three other states - Idaho, Nebraska, and Utah - to put expansion to a vote in November 2018. The measures passed in all three states, placing the decision of the public at odds with the policymakers that had previously opposed it. Although other states could follow a similar path to expansion, there are important limitations to this approach that should be considered.

Fourteen states have not expanded Medicaid, but ballot initiatives are not an option for most of them. Our analysis of all state constitutions found that only six-Florida, Mississippi, Missouri, Oklahoma, South Dakota, and Wyoming - have not expanded Medicaid and allow ballot initiatives (see Table 1).

Yet, even amongst those states that are eligible for expansion by ballot initiative, the laws that govern the development,

Received January 29, 2019

Revised March 6, 2019

Accepted April 12, 2019

Published online May 28, 2019 scope, and implementation of an initiative vary widely. This variation includes limiting an initiative to a single subject, which narrows the scope of allowable statutory language. This in turn places constraints on implementation and provides opponents of expansion a pressure point on which to contest the legality of the initiative. In Nebraska, the single subject requirement led initiative supporters to exclude a specific funding mechanism to cover expansion costs, increasing the challenges of implementation. Of the states yet to adopt expansion, only South Dakota and Mississippi do not include this requirement.

Given that an attempt to expand Medicaid by ballot initiative suggests that state political leadership has not been amenable to expansion, even once passed, the law is at risk of being altered by elected policymakers. Each non-expansion ballot initiative state allows for the legislature to amend or repeal any passed initiative, though some differences exist in their scope and timing. In seven of the states which have passed or could pass expansion through an initiative, amending or repealing the statutory language include in the initiative requires only a simple majority vote by the legislative branch, with Florida, Mississippi, and Nebraska requiring the legislative chamber to have a supermajority of threefifths (Florida) to two-thirds (Mississippi and Nebraska). Additionally, only one state - Wyoming - requires the legislature to wait any time period before repealing the expansion initiative, with all other states allowing immediate repeal. Though there is serious political risk, policymakers in each of the three states that passed an initiative in 2018 have begun discussion on whether to alter or repeal the expansion, with Utah passing legislation fundamentally altering the expansion program passed through the ballot initiative.

Republicans in each of these states control the executive and all chambers of the legislature (except Maine, where Democrats controlled the House of Representatives before the 2018 election and now control the governorship and legislature). Excluding Maine, on average, Republicans control $72 \%$ of the total legislative seats, ranging from $60 \%$ in Florida to $87 \%$ in Wyoming. Though Republicans in many states have supported Medicaid expansion, including by championing expansion efforts in 2018 and before, the opposition to expansion in the remaining non-expansion states comes largely from Republican policymakers and a party-line vote can alter a successfully passed initiative. 
Table 1 Non-expansion States Which Allow Ballot Initiatives

\begin{tabular}{|c|c|c|c|c|c|}
\hline State & $\begin{array}{l}\text { Governor's } \\
\text { party }\end{array}$ & $\begin{array}{l}\text { Legislative } \\
\text { control } \\
\text { (upper/lower) }\end{array}$ & $\begin{array}{l}\text { Percent of seats } \\
\text { held by } \\
\text { Republicans } \\
\text { in legislative } \\
\text { chambers }\end{array}$ & $\begin{array}{l}\text { Single } \\
\text { subject } \\
\text { requirement }\end{array}$ & Legislative input on ballot initiative \\
\hline Florida & $\mathrm{R}$ & $\mathrm{R} / \mathrm{R}$ & $60 \%$ & Yes & $\begin{array}{l}\text { Amend or repeal ballot initiative with } \\
3 / 5 \text { supermajority }\end{array}$ \\
\hline Idaho & $\mathrm{R}$ & $\mathrm{R} / \mathrm{R}$ & $80 \%$ & No & $\begin{array}{l}\text { Amend or repeal ballot initiative with } \\
\text { simple majority vote }\end{array}$ \\
\hline Maine & $\mathrm{D}$ & $\mathrm{D} / \mathrm{D}$ & $37 \%$ & No & $\begin{array}{l}\text { Amend or repeal ballot initiative with } \\
\text { simple majority vote }\end{array}$ \\
\hline Mississippi & $\mathrm{R}$ & $\mathrm{R} / \mathrm{R}$ & $62 \%$ & No & $\begin{array}{l}\text { Amend or repeal ballot initiative with } \\
2 / 3 \text { supermajority }\end{array}$ \\
\hline Missouri & $\mathrm{R}$ & $\mathrm{R} / \mathrm{R}$ & $72 \%$ & Yes & $\begin{array}{l}\text { Amend or repeal ballot initiative with } \\
\text { simple majority vote }\end{array}$ \\
\hline Nebraska & $\mathrm{R}$ & $\mathrm{R}^{*}$ & $61 \%$ & Yes & $\begin{array}{l}\text { "Amend, repeal, modify or impair" } \\
\text { ballot initiative with } 2 / 3 \text { supermajority }\end{array}$ \\
\hline Oklahoma & $\mathrm{R}$ & $\mathrm{R} / \mathrm{R}$ & $77 \%$ & Yes & $\begin{array}{l}\text { Amend or repeal ballot initiative with } \\
\text { simple majority vote }\end{array}$ \\
\hline $\begin{array}{l}\text { South } \\
\text { Dakota }\end{array}$ & $\mathrm{R}$ & $\mathrm{R} / \mathrm{R}$ & $85 \%$ & No & $\begin{array}{l}\text { Amend or repeal ballot initiative with } \\
\text { simple majority vote }\end{array}$ \\
\hline Utah & $\mathrm{R}$ & $\mathrm{R} / \mathrm{R}$ & $78 \%$ & Yes & Amend ballot initiative with simple majority vote \\
\hline Wyoming & $\mathrm{R}$ & $\mathrm{R} / \mathrm{R}$ & $86 \%$ & Yes & $\begin{array}{l}\text { Amend ballot initiative with simple majority vote; } \\
\text { cannot repeal initiative for } 2 \text { years }\end{array}$ \\
\hline
\end{tabular}

*Nebraska has a non-partisan and unicameral state legislature. Percent of Republican-held seats came from party affiliation of Nebraska legislators

The challenges that may await states after a successful initiative are illustrated by Maine's experience. Outgoing Republican Governor Paul LePage has been a vocal critic of Medicaid expansion, vetoing five previous legislative attempts to expand the program. The morning after the successful passage of the ballot initiative, LePage announced that he would not enforce the initiative until the legislature appropriated money necessary to cover the state's portion of the expansion costs, ${ }^{1}$ while later threatening a veto if the legislature failed to adhere to his requirements for how the program should be funded. ${ }^{2}$ The disagreement was taken to the courts, where the Maine Supreme Court held that the ballot initiative was clear in requiring the state to expand Medicaid. Though the LePage Administration continued to hinder implementation, the matter was settled when newly elected Democratic Governor Janet Mills signed an executive order to expand Medicaid ahead of a deadline previously set by the courts. ${ }^{3}$

Successful initiative states will need to identify funding sources for their expanded Medicaid programs. Beginning in 2020 , states will fund $10 \%$ of the cost of expansion, though this is unlikely to represent a significant portion of state spending. ${ }^{4}$ Of the three states that passed expansion by initiative in 2018, only Utah included a specific funding mechanism as part of the proposed statutory language, increasing the sales tax on non-food items. ${ }^{5}$ Excluding specified funding is a double-edged sword for passage and implementation of expansion. It simplifies the initiative and increases the chance of passage by relieving the public of any responsibility to decide on raising revenues or service cuts. It also avoids fueling opposition from interests harmed by the funding choices, as seen in Montana when a ballot initiative to increase a tobacco products tax to fund their expansion program failed after opposition by tobacco companies campaigned against the measure. Yet, if an expansion initiative passes without a funding mechanism, it increases the uncertainty of implementation, with a potentially unsupportive legislature and executive making budgetary decisions, as seen in Maine.

The Trump Administration can alter the politics of a state pursuing and implementing a ballot initiative by signaling increased flexibility for Medicaid. State policymakers can leverage this flexibility through Section 1115 waivers to introduce more conservative elements in their expansion programs, including health savings accounts, healthy behavior incentive programs, and cost-sharing; no ballot initiative state included these elements. In addition to these elements, states may attempt to add work requirements, lifetime limits, and other changes to align the Medicaid program with their political ideology, as Utah has done. ${ }^{6}$ Recently released guidance from the Centers for Medicare \& Medicaid Services (CMS) on Section 1332 waivers provides new guidance that favors private over public insurance and opens up new opportunities for state policymakers to reject Medicaid expansion and pursue private options, such as offering noncompliant or short-term insurance plans, to bridge the coverage gap.

Expansion by ballot initiative is not without its unique challenges. While predictions about the future of health reform have focused on the role of state governments, it may be the citizens that drive future expansions of health coverage. Whether a state adopts the Medicaid expansion has important implications on the health workforce. Medicaid expansion offers the newly insured access to health insurance, while the newly insured have used this insurance, challenges remain in meeting their needs, including physicians and staff meeting the increased demand. ${ }^{7}$ Across each of the prior successful ballot initiative, physicians have played a key role. They have provided organizational endorsements, volunteering for the 
campaigns, or raising a public voice in favor of expansion. Though there are serious challenges, these pioneering successes in some of the USA's most politically conservative environments suggest that coverage expansions may continue to spread across the country.

Acknowledgments: The authors would like to thank Benjamin Sommers for helpful comments and feedback on an earlier draft of the manuscript.

Corresponding Author: Phillip M. Singer, PhD, MHSA; Department of Political Science, University of Utah, Salt Lake City, UT, USA (e-mail: phillip.singer@poli-sci.utah.edu).

\section{Compliance with Ethical Standards:}

Conflict of Interest: Daniel Nelson was an unpaid policy advisor for Reclaim Idaho, an organization that supported the Medicaid expansion ballot initiative in Idaho; all remaining authors declare that they do not have a conflict of interest.

\section{REFERENCES}

1. Governor LePage issues statement on Medicaid expansion. Maine Office of the Governor website. https://www.maine.gov/tools/whatsnew/index. php?topic $=$ Gov + News\&id $=771214 \& v=$ article2011. Accessed March 5, 2019.

2. Governor LePage sends letter to legislative leadership outlining principles of Medicaid expansion. Maine Office of the Governor website. https://www. maine.gov/governor/lepage/newsroom/article.html?id=773595. Accessed March 5, 2019.

3. Executive Order 01. Maine Office of the Governor. https://www.maine gov/governor/mills/sites/maine.gov.governor.mills/files/inline-files/ Executive\%20Order\%201.pdf. Accessed March 5, 2019.

4. Goldman AL, Sommers BD. Kansas and Medicaid: New Evidence on Potential Expansion and Work Requirements. The Commonwealth Fund Issue Brief. September 2018.

5. Pear R. A groundswell builds for expanding Medicaid in conservative Utah The New York Times. September 9, 2018 https://www.nytimes.com/ 2018/09/09/us/politics/utah-medicaid-expansion.html. Accessed March 5, 2019

6. Singer PM, Nelson DB, Tipirneni R. Consumer-directed health care for Medicaid patients: Past and future reforms. Am J Public Health. 2017;107(10):1592-1594

7. Miller S, Wherry LR. Health and access to care during the first 2 years of the ACA Medicaid expansions. N Engl J Med. 2017;376(10):947-956.

Publisher's Note Springer Nature remains neutral with regard to jurisdictional claims in published maps and institutional affiliations. 